\title{
Grammatical Cohesive Devices in Reading Text: A Discourse Analysis of English Test for Junior High School
}

\author{
${ }^{1}$ Dwi Jayanti, ${ }^{2}$ Didin Nuruddin Hidayat* \\ UIN Syarif Hidayatullah Jakarta \\ *Corresponding Author \\ Email: didin.nuruddin@uinjkt.ac.id
}

\begin{abstract}
Reading text, besides being used as teaching media, is also used in an assessment measurement. However, in reality, many students have difficulty understanding the reading text due to several factors such as the text is too long, incohesive between words, and even incoherent between paragraphs. To avoid these factors, important to analyze the use of cohesive devices in reading texts. The present study aimed to investigate grammatical cohesive devices in the reading text of the English National Final Examination test for Junior High School in the 2017-2018 academic year in Indonesia. The current research attempted to: (1) find out the kind of grammatical cohesion devices that were applied in sixteen reading texts of the English National Final Examination test, (2) explore the use of reference, substitution, ellipses, and conjunction to describe the cohesiveness that was applied in sixteen of the reading texts, consisting of a short functional, narrative, descriptive, recount and report text. The reading texts were analyzed using Halliday and Hasan's (1976) theory related to grammatical cohesion devices. The steps of data analysis were through the process of collecting, counting, categorizing, and assessing the grammatical cohesion devices. The findings revealed that 621 grammatical cohesion devices were used in the English National Final Examination reading text. Further, the findings explained that $67.47 \%$ of grammatical cohesion device was the reference (419), 5.15\% was the substitution (32), $2.58 \%$ was the ellipses (16), 24.80\% was the conjunction (154). The findings also indicated that the limited use of grammatical cohesion devices in the present study showed a lack of a variety of grammatical cohesion in terms of form and variation devices. Although the reading text of the English Final Examination was somewhat cohesive, some areas still need improvement. Implications for teachers and educators are to give more attention to the coherence of the reading text. A cohesive reading text will provide an understanding of both the form and content of the text. For reading text scriptwriters, they must pay attention to grammatical cohesion devices so it becomes more varied and not monotonous. Besides, students need to be given material related to cohesion because knowledge of cohesion is very useful in the mastery of their language, especially in reading and writing skills.
\end{abstract}

Keywords: English National Examination test, grammatical cohesion devices, reading text

\section{INTRODUCTION}

Reading is one of the most important ways of learning, as it is connected with literacy and civilizational development as well, "since 2008, a growing number of developing countries are assessing the reading skills of pupils in the early grades of primary school" (UNESCO, 2012). This activity is very crucial not only on personal achievement but also on society as a whole, and ignorance of this important activity, especially at an early age, means many learning problems, "students who cannot read do not have the prerequisite skills for successful learning in the next level" (UNESCO, 2012). 
In order to achieve effective reading learning, the teacher must design the material that will be taught. The reading material consists of the integrity of language components such as sound systems, grammar, and vocabulary. In other words, the teacher must provide reading texts that can provide useful information in language learning. Besides, it can also be an assessment tool for teachers to measure the students' reading ability. One of the reading texts used as an assessment tool is the English national examination reading text. National examination reading texts have gone through a series of selection and supervision processes handled directly by the Indonesian Ministry of Education and Culture (PUSPENDIK, 2018).

The skills that will be measured in English National Final Examination are reading skills. At the junior high school level, all the material is in reading text. Meanwhile, at the senior high school level, reading covers $70 \%$ of all of the English National Final Examination content, and the rest is the listening section (Badan Standar Nasional Pendidikan, 2017). Readers, in this case, students must obtain precise information from the texts. They must understand the reading texts before answering the questions. The problem is that many students still find difficulties in comprehending the reading texts. The low mastery of grammar, limitation of vocabulary, and the understanding of coherence and cohesion in a text impact them in answering the Final Examination test (Ekawati et al., 2011).

Many pieces of research have explored the grammatical cohesion devices in students' writing (e.g., Abdurahman, 2013; Bahaziq, 2016; Nasser, 2017; Trisnaningrum et al., 2019). The Abdurrahman's study (2013) for example, used the descriptive case study method. He found that the use of grammatical cohesion in the thesis text of language education program students was able to achieve the use of various grammatical types (1273 findings), with the most consecutive findings being references, conjunctions, ellipses, and substitutions. However, in many cases, the tendency for error lies in the misuse of singular pronouns when referencing plural objects or vice versa. From these results, it was also found that $5.81 \%$ (74 findings) was a grammatical cohesion device that used inappropriately. Meanwhile, Nasser's study in 2017 focused on the discourse errors in using grammatical cohesive devices in argumentative texts written by Yemeni EFL learners. The findings also revealed that the category of errors in the use of reference ties was the most problematic category in which the learners made the most frequent errors, while the category of errors in substitution and ellipsis was the least frequent one. According to frequency, orderly error level is as follows: reference error, conjunction error, substitution error, and ellipsis error. While the research conducted by Bahaziq (2016) and Trisnaningrum (2019) both indicated that the most findings were on reference and conjunction, Bahaziq's research emphasizing the lack of findings on the use of lexical devices, which resulted in less cohesive text. Meanwhile, research by Trisnaningrum (2019) indicates the lack of grammatical cohesion devices use in terms of comprehension, knowledge, and ability in writing leads college students to use inappropriate grammatical cohesion devices.

Nevertheless, there is scant information on research studies exploring language testing documents, such as the English National Final Examination (Ekawati et al., 2011). In a study conducted by Ekawati using a qualitative approach to the reading text of the English national examination for high school level, she found many grammatical cohesion devices used and lexical cohesion devices. She 
also concluded that the text of the English National Examination of the senior high school level had met the cohesive criteria. It means the scriptwriter of the national examination reading text already paying attention to the element of cohesiveness in the text. As a consequence, it is become easier to understand each sentence and paragraph.

Based on the aforementioned above, the present study investigates the quality of the English National Final Examination for Junior High School, specifically in the grammatical cohesion. The cohesion aspect of the English National test will contribute to students' understanding of the reading texts. It is difficult for students to understand the reading text if there is a limited cohesion aspect, which leads to difficulty in answering the questions (Ekawati et al., 2011). The information on the quality of cohesiveness of the English National Examination test will be useful for teachers and educators in developing the materials in teaching and learning or even make a qualified test item in English National Final Examination. The earlier these EFL are introduced to grammatical cohesion devices. It is hoped that the more familiar they will be. Thus it will support their learning process of English in the future

One way to determine a good paragraph in the English National Final Examination text is from the coherence and cohesion. According to Oshima (1998), cohere comes from the Latin verb that means to hold together. The coherence in a text is indicated by the sentences that must hold altogether, which is, the movement from words and sentences ones to others must make sense, logical and smooth (Oshima, Alice \& Hogue, 2006). It indicates that there are no abrupt transitions. Each word, phrase, and sentence should flow smoothly from one to another. To measure the coherence and the cohesion of the text, we need to use cohesive devices analyses.

According to Halliday and Hasan (1976), cohesion is a set of resources in language to make texts have unity. A discourse or text uses a cohesive device to keep cohesiveness. A text is categorized as a cohesive text if the components are stick together and are critical interpretations to the readers. Cohesion occurs when the interpretation of one component depends on another component; for example, one component presupposes another (Halliday \& Hasan, 1976). Cohesion is related to vocabulary and grammar; therefore, it is concerned with grammatical and lexical cohesion.

Halliday and Hasan (1976) claimed that to produce a cohesive text, we need to use cohesive devices. Cohesive devices consist of six types. They are four types of grammatical cohesion, namely reference, substitution, ellipse, and conjunction. Meanwhile, for lexical cohesion, there are two types, namely reiteration, and collocation. In this research, the focus research is only on the use of grammatical cohesion devices. They are reference, substitution, ellipsis, and conjunction.

Halliday and Hasan (1976) described grammatical cohesion as how grammatical features construct together across sentence boundaries. The grammatical cohesion devices divided into four types. Reference is the relation between an element of text and others by reference to which it is interpreted. Substitution is a condition when an item is replaced by another item to avoid repetition, while the ellipsis is the process of omitting an item that has been mentioned previously in the text. The conjunction is a linking device between sentences or clauses in the text. 
Based on the description above, the theory of Halliday and Hasan (1976) became a pioneer for the next researchers to develop the concept of grammatical cohesion devices. For instance, Bahaziq (2016) explained that reference is indicated as a condition in which one component cannot be interpreted semantically unless referred to as another component in the text. Personal pronoun, demonstrative, and comparative are used to refer to items in linguistic or situational texts. He also stated that substitution is used to avoid repetition; substitution occurs when an item is replaced with another item in the text. The difference between reference and substitution is that the reference lies between the meanings, while the substitution lies in the relationship between words. Substitution is divided into three types, namely nominal, verbal, and causal. Furthermore, the ellipsis device is the idea of omitting part of a sentence assuming that the previous sentence will clarify the meaning (Trisnaningrum et al., 2019). The last is the conjunction that refers to words to relate two or more words and sentences, such as additive (and), adversative (but), causality (because), and temporal (time) (Almutairi, 2017).

From the description above, the researchers adopted the conceptual framework of grammatical cohesion devices from Halliday and Hasan (1976) as cited in Afrianto (2017):

Table 1. The Conceptual Framework of Halliday and Hasan's Theory in Grammatical Cohesion Devices

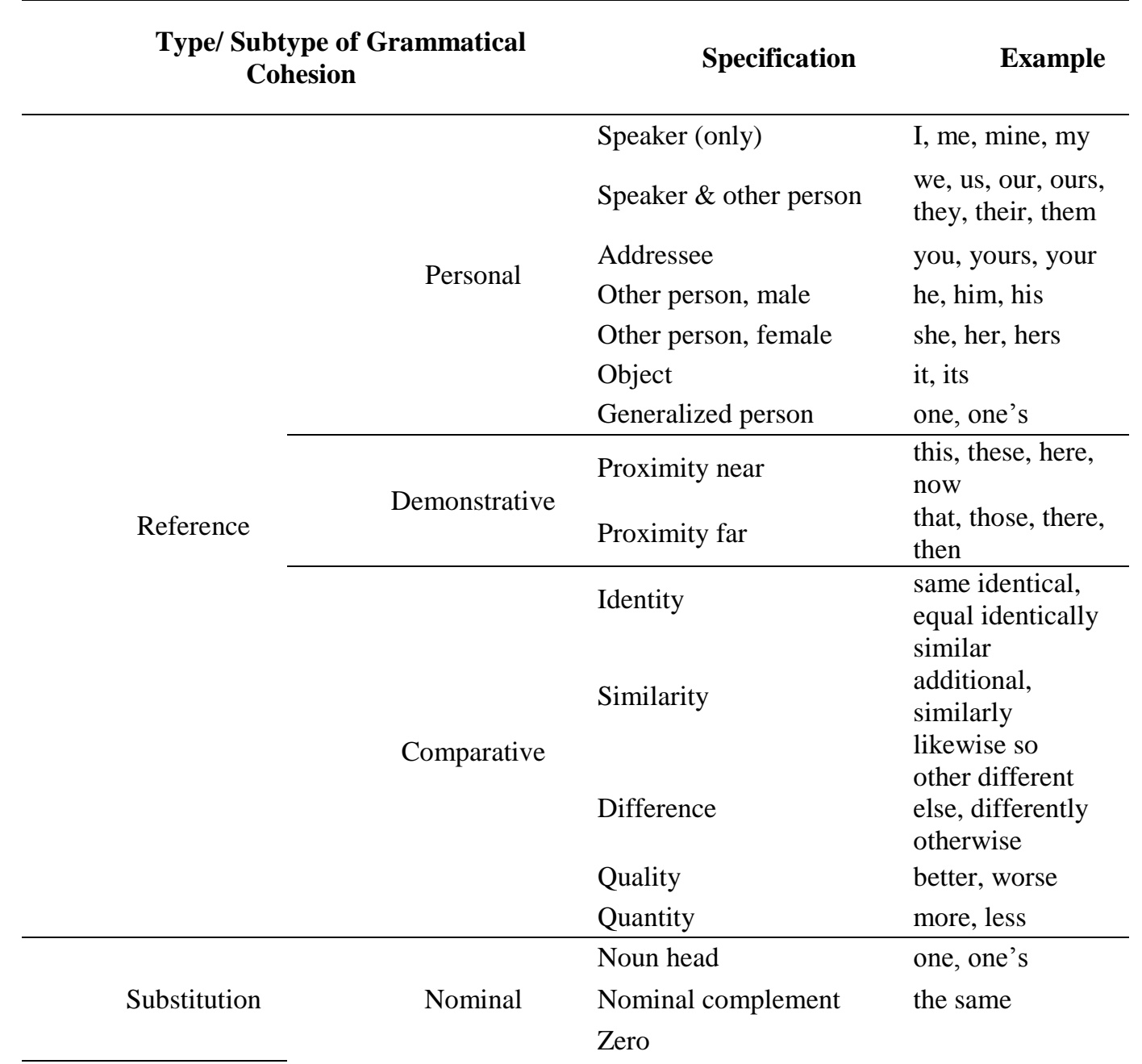


Journal of English Teaching Adi Buana, Vol. 06 No. 01, April 2021

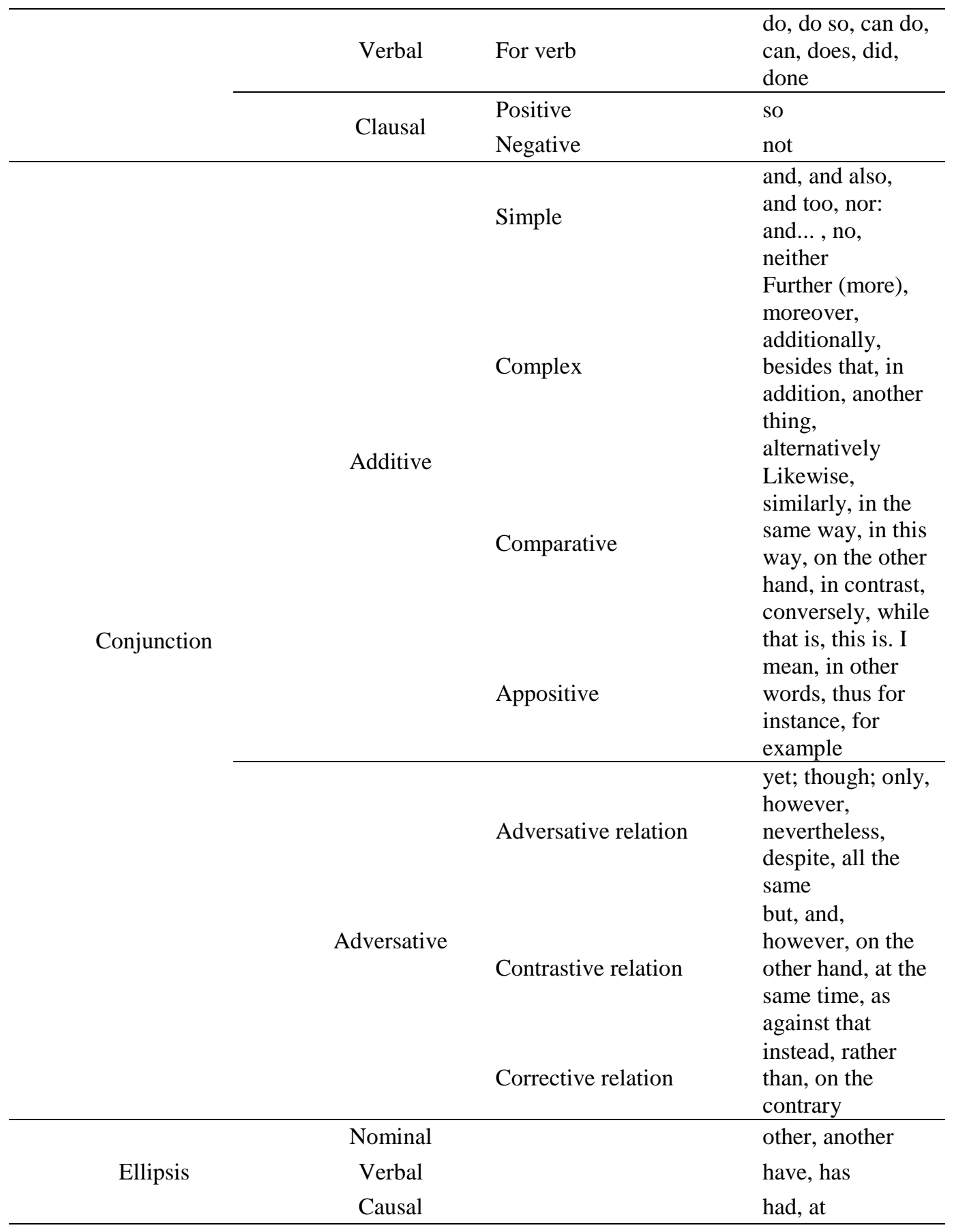

Based on that background, the researchers focused on analyzing grammatical cohesion devices used in sixteen reading texts of the English National Final Examination. The English National Examination test selection is to find out the quality of reading text in terms of grammatical cohesion devices. Hence, the researchers conducted this analysis to find out grammatical cohesive devices in the reading texts of English National Final Examination for Junior High School in the 2017-2018 academic year. The objectives of the study are: (1) to find out the kind of grammatical cohesion devices that were applied in sixteen reading texts of the English National Final Examination test, (2) explore the use of reference, substitution, ellipses, and conjunction to describe the cohesiveness that was applied 
in sixteen of the reading texts of the English National Final Examination test

\section{METHOD}

This research applied the descriptive-analytical research approach to analyze the use of grammatical cohesion devices in reading texts. The research applied Halliday and Hasan's theory of grammatical cohesion devices to identify, analyze, and interpret grammatical cohesion devices used in the reading text of the English National Final Examination in Junior High School year 2018. Descriptive statistics allow the researcher to describe data and examine the result that provides information about the condition, situation, and events in the present (Luke \& Dooley, 2011). Then the reading text was examined to evaluate the quality in terms of grammatical cohesion devices.

The data were collected from the copy sheet of the English National Final Examination year 2018. This research took only one sample of test packages from many test packages since it was considered that the test similar in the content and differ only in the position of the test number. The steps to analyze the data are: (1) Collecting the copy sheet of English National Final Examination year 2018. (2) Counting every grammatical cohesive device and inputting them based on the classification in each table of types of cohesive (see appendices). (3) Categorizing the cohesive devices with the formula:

$$
P=\frac{N}{T} \times 100 \%
$$

Which, $\mathrm{P}=$ Percentage

$\mathrm{N}=$ Types or sub-types of a grammatical cohesive device

$\mathrm{T}=$ Total Grammatical cohesive devices in reading text National Exam

(4) and Assessing the correctness and incorrectness of grammatical cohesive devices.

\section{RESULTS AND DISCUSSION}

The result of the data analysis are as follows:

\section{The Use of Grammatical Cohesion Devices}

This part explained the use of grammatical cohesion devices in the English National Final Examination reading text. Some explanations in this part show some devices are dominantly used while other devices are not. Table 2 shows the result.

Table 2. The Most Frequent Use of Grammatical Cohesion Devices Types

\begin{tabular}{ccc}
\hline $\begin{array}{c}\text { Type of } \\
\text { Grammatical Cohesion } \\
\text { Devices }\end{array}$ & \multicolumn{2}{c}{$\begin{array}{c}\text { Reading Text Grammatical } \\
\text { Cohesion Devices Use }\end{array}$} \\
\cline { 2 - 3 } & $\mathrm{N}$ & $\%$ \\
References & 419 & $67,47 \%$ \\
Substitution & 32 & $5,15 \%$ \\
Ellipsis & 16 & $2,58 \%$ \\
Conjunction & 154 & $24,80 \%$ \\
Total & 621 & $100 \%$ \\
\hline
\end{tabular}


Table 2, reference is the most dominant grammatical cohesion devices used by the English Final Examination scriptwriter, took $67.47 \%$ of the grammatical cohesion devices. The second position is the conjunction coverage of $24.80 \%$. On the other hand, the use of substitution and ellipsis is in a low rank. They are in the third and fourth position is substitution $(5.15 \%)$ and ellipsis $(2.58 \%)$. The data shows that the English National Final Examination scriptwriter is very few to use the substitution and ellipsis as grammatical cohesion devices. This assumption indicated that the students of Junior High School are still rarely exposed to the grammatical cohesion devices in terms of comprehension, forms, and variations, specifically in substitution and ellipsis. Moreover, this finding is similar to Abdurrahman (2013), which stated that reference was the most dominant use with $82.3 \%$, then conjunction $17.2 \%$, substitution $0.3 \%$, and followed by ellipsis $0.4 \%$.

The explanation of each type of subtype grammatical cohesion device in the reading text of the English National Examination is shown below. There are four types of pie charts representing each type of cohesion device: reference, conjunction, substitution, and last is an ellipsis. Each part represents each sub-type and the percentage of the use in each sub-type grammatical cohesion device. The pie chart figures are as follows.

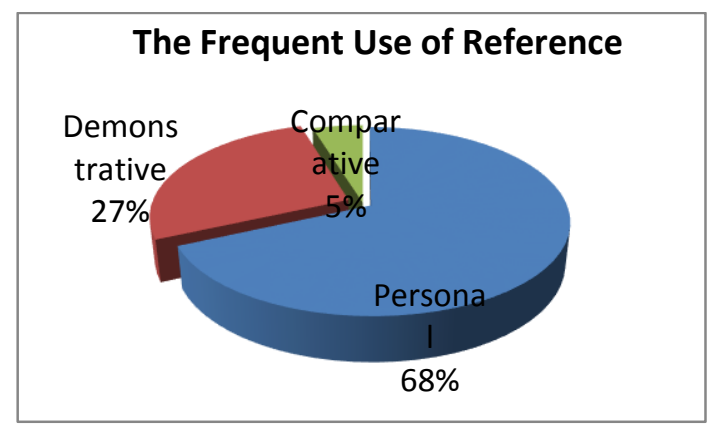

Figure 1. The use of reference

From the pie chart above, the figure shows that the most use grammatical cohesion devices compared to the others. In frequent reference, the subtype of personal reference is the most dominant with $68 \%$, followed by demonstrative $(27 \%)$ and comparative (5\%).

In this study, researchers found many reference devices used. Forms of reference can be realized through a personal pronoun that includes a first-person reference, a second-person reference, and a third-person reference. The number of reference devices shows that the scriptwriter of the national examination reading text has paid attention to the coherence element in a reading so that it is easy to understand each sentence and paragraph. In general, references widely used are references to personal pronouns such as my,his, her, and it. Also references to a place like that and there.

Next, for the frequent use of conjunction grammatical cohesion devices, the most dominant is additive conjunction with $86 \%$, then adversative conjunction with $14 \%$. The pie chart as follows: 


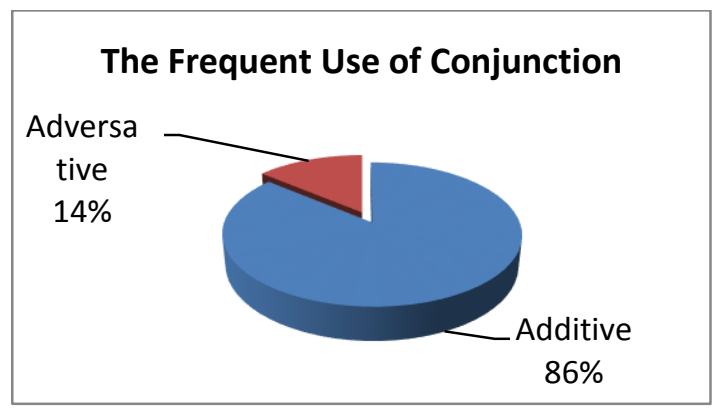

Figure 2. The use of conjunction

As described before, the function of this conjunction device is to concatenate or connect between sentences one with other sentences in the same discourse. Conjunction devices are divided into additive (addition) and adversative (contradiction) conjunction. Conjunction additive connects two elements of language that have the same position, like a connecting device. While adversative conjunctions occur when what is stated in the first clause opposite or not equal to what is stated in the second clause.

Researchers found the use of additive conjunctions was more dominant than adversative conjunctions. This can be seen from the many uses of conjunctions such as and, also, else in abundance and repetition. However, the use of adversative conjunctions is limited to forms such as only and but.

Based on these findings, it shows that the reading text of the junior high school level national exam has used conjunction devices, both additive and adversative so that the text is categorized as a cohesive one. However, the use of a more varied additive conjunction is highly recommended so that students have a lot of new vocabulary in the term additive conjunction. Furthermore, the use of the adversative conjunction also needs to be added so that students get more vocabulary related to the adversative conjunction.

Furthermore, for substitution devices, the frequent use of substitution is verbal substitution with $47 \%$, followed by nominal $(28 \%)$ and clausal substitution with $25 \%$. The pie chart is shown below:

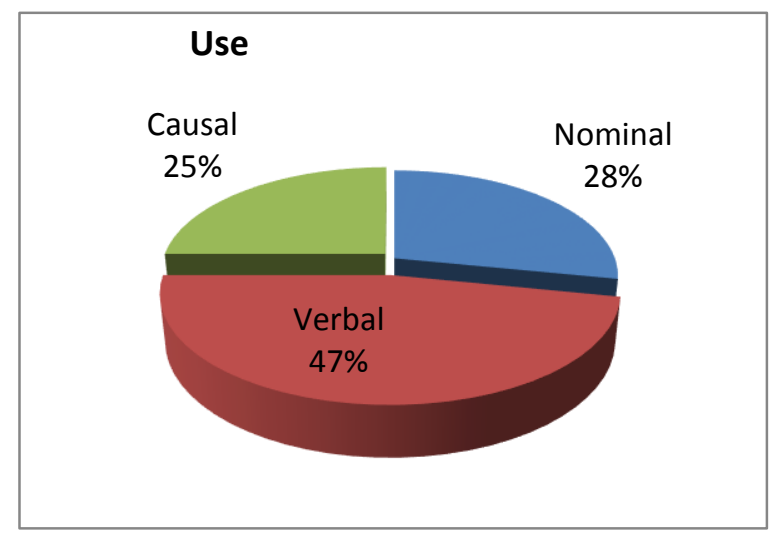

Figure 3. The use of substitution

Substitution or replacement is a device of its cohesion indicates a word replacement or a later phrase not mentioned again in the next clause or sentence. The function of using the substitution device is a substitute for the word to create a 
change in form variations, so there is no monotony, and sentences that are created become more dynamic. The researchers found that the sentences using substitution were quite evenly distributed and varied. These words include substitution devices such as one, ones, do, did and so. This shows there is a relationship between one sentence with another. In this case, the replacement of the phrase also has a function that provides a variety of form, creates dynamic sentences, and eliminate monotony.

In the last chart, ellipsis devices, the most dominant use is nominal ellipsis, with $42 \%$, followed by causal $(36 \%)$ and verbal ellipsis $(22 \%)$. The pie chart as follows:

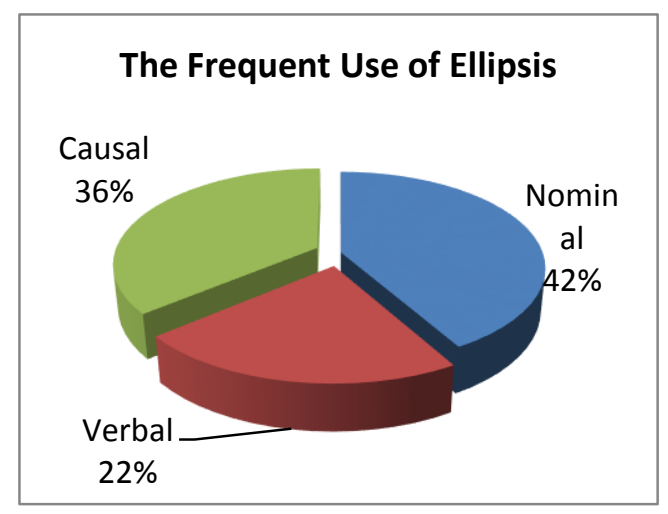

Figure 4. The use of ellipsis

In this study, 16 ellipsis devices were found to be used. These devices include the uses of other, have, and had, which are found in several places. It shows that the scriptwriter of the English national examinantin of the junior high school level has paid attention to the coherence element. This device makes sentences more concise, furthermore avoids using repeated words or phrases.

Based on the explanations above, the grammatical cohesion device with the highest frequency is the personal reference, with $68 \%$. It has similar findings with Almutairi (2017), in which personal references became the most used reference with 76\%. Moreover, Almutairi's research finding also shows that the second position is a nominal substitution with $71 \%$, followed by additive conjunction with 58\% (Almutairi, 2017).

\section{The Specification of Grammatical Cohesion Devices}

The specification of grammatical cohesion devices pointed out the description of grammatical cohesion devices use in detail. This description may assume the level of cohesiveness, form, and variations of vocabulary devices used in reading text English Final Examination. The description of grammatical cohesion devices use presented in Table 3 below.

Table 3. Description of Grammatical Cohesion Devices Use

\begin{tabular}{ccccc}
\hline $\begin{array}{c}\text { Type of } \\
\text { grammatical } \\
\text { cohesion devices }\end{array}$ & $\begin{array}{c}\text { A subtype of } \\
\text { grammatical } \\
\text { cohesion devices }\end{array}$ & $\begin{array}{c}\text { The kinds of } \\
\text { grammatical } \\
\text { cohesion devices } \\
\text { in reading text } \\
\text { of English } \\
\text { National Final } \\
\text { Examination }\end{array}$ & $\begin{array}{c}\text { The number of } \\
\text { grammatical } \\
\text { cohesion } \\
\text { devices uses }\end{array}$ & $\%$ \\
\hline
\end{tabular}




\begin{tabular}{|c|c|c|c|c|}
\hline \multirow{2}{*}{ References } & Personal & $\begin{array}{l}\text { my, his, her, } \\
\text { them, us, our, } \\
\text { their, it }\end{array}$ & 284 & $45,73 \%$ \\
\hline & Demonstrative & this, that, there & 115 & $18,52 \%$ \\
\hline \multirow{4}{*}{ Substitution } & Comparative & same, other, so & 20 & $3,22 \%$ \\
\hline & Nominal & one, ones & 9 & $1,45 \%$ \\
\hline & Verbal & do, did & 15 & $2,42 \%$ \\
\hline & Causal & so, not & 8 & $1,29 \%$ \\
\hline \multirow{3}{*}{ Ellipsis } & Nominal & other, another & 8 & $1,29 \%$ \\
\hline & Verbal & have, had & 3 & $0,48 \%$ \\
\hline & Causal & had, at & 5 & $0,81 \%$ \\
\hline \multirow{2}{*}{ Conjunction } & Additive & $\begin{array}{l}\text { and, also, else, } \\
\text { that is }\end{array}$ & 129 & $20,77 \%$ \\
\hline & Adversative & $\begin{array}{l}\text { only, but, or, } \\
\text { however }\end{array}$ & 25 & $4,03 \%$ \\
\hline ota & & & 62 & $100 \%$ \\
\hline
\end{tabular}

From Table 3, the researchers classified the types of grammatical cohesion devices used into four types: references, ellipsis, substitution, and conjunction. The description of the table as follows:

\section{Reference}

From the analysis, the study found that 284 personal references are used in the reading text of the English National Examination. The personal references used by the scriptwriter such as my, her, his, them, our, us, their, and it. These personal references are regarding the short functional text, writing narrative, and recount text that includes a person and the object as references. The findings also showed that the use of this, that, and there also found 115 words represent it. The use of same, other and so with total 20 also found to indicate the comparative references.

\section{Substitution}

The study found that verbal substitution is the most used device in substitution types, with 15 verbal substitutions. The use of $d o$ and $d i d$ are to show the past activities. Then, there are nine (9) devices for the nominal substitution, such as one and ones. Besides causal substitution specification, there are eight (8) devices, such as other and another. The nominal and verbal substitution are commonly found in the report and descriptive texts to substitute the previous object being discussed.

\section{Ellipsis}

In terms of ellipsis, the study found fewer devices compared to other devices. For nominal ellipsis, the study found eight (8) devices. There are three (3) and five (5), respectively, for verbal and causal ellipsis. The most used verbal ellipsis is the use of other and another that omitted another object to replace the previous nominal in short functional texts. Furthermore, the use of causal and verbal ellipsis, such as have, had, at, also are found in the narrative, recount, report, and descriptive texts.

\section{Conjunction}

The next grammatical cohesion device to measure the cohesiveness is conjunction devices. From the analysis, the most dominant conjunction found was 
additive conjunctions such as and, also, else, that is, accounting for 129 in total. This finding contradicts the finding of adversative conjunction, with only 25 adversative conjunctions in English National Examination. The adversative conjunction found in this text is only, but, or, however, with the total 25 . The findings indicate that there is a gap in the use of additive conjunction and adversative conjunction.

Moreover, the kind of conjunction used in the English Final Examination (Table 3 ) is still limited and monotonous compared with the conjunction that may be used (in Table 1). The use of adversative conjunction devices needs to improve by giving variations of grammatical cohesion devices, specifically in conjunction devices. It will give a chance to students to get experience in using different variations of grammatical cohesion devices. Hence, the students will be more familiar with many kinds of grammatical cohesion devices.

From the findings above, the analysis reveals that the use of grammatical cohesion devices in the reading text of English National Final Examination for Junior High School academic year 2018 is reference devices as dominant devices with $67.47 \%$ and the rest $32.63 \%$ are conjunction, substitution, and ellipsis. In a similar result, if the text is compared to the other text of English testing document, most of the testing document used in the grammatical cohesion devices is the reference, and rarely used in substitution and ellipsis (Ekawati et al., 2011; Faizah et al., 2020; Laeli, 2015).

One of the qualifications of a good paragraph in the English National Final Examination text is coherence and cohesion. According to Oshima and Hogue (2006), cohere comes from the Latin verb that means "hold together." The coherence in a text is indicated by the sentences that must hold altogether, which is, the movement from words and sentences ones to others must make sense, logical, and smooth. It indicates that there are no sudden jumps. Each word, phrase, and sentence should smooth flowing from one into the next one. The contribution of coherence comes from cohesion for linking one part of the text to another. To verdict the text's coherence and cohesiveness, specifically the English National Final Examination reading text, we need to use cohesive devices.

Based on the qualification above, the findings indicate that the reading text of the English National test fulfills the criteria of cohesion. Cohesion occurs in the text if it has texture. In other words, a text is cohesive when language overlays are hung together with ties. Halliday and Hasan (1976) emphasized that these ties in a similar vein are found in grammatical ties.

However still, there are many gaps found from the analysis of the data. The findings indicate a gap, especially in the use of additive conjunction and adversative conjunction. From 154 conjunctions, 129 is additive conjunction with around $82 \%$, and 25 is adversative conjunction with around $18 \%$ from all of those of conjunctions. The additive conjunctions exposed in the text are five times more than the adversative conjunction. These significantly different results are in line with Ardanellia \& Pasaribu's (2019) study stating that the additive conjunction appears on percentage $71.22 \%$, the conjunction and is the most used in the descriptive text, which is used 297 times. This finding is in line with Nugraheni's (2015) result, in which the additive conjunction is repeated many times and raises almost 50\% used from all the forms of conjunctions. The type of text used to be analyzed in this research was descriptive text, in which the text tended to give more description and 
explanation about objects related to a certain topic (Nugraheni, 2015). The reason is that EFL learners prefer to evolve their text by giving descriptions, examples, and details related to a certain topic rather than exploring arguments (Pasaribu, 2017).

Moreover, the conjunctions used in the English Final Examination (Table 3) are still limited and monotonous compared with the conjunction that may be used (Table 1). The use of adversative conjunction devices needs to improve by giving variations of grammatical cohesion devices, specifically in conjunction devices. The analysis of the data also assumed that the English National Final Examination text is only familiar with some types or kinds of grammatical cohesion devices. Fortunately, this reading text is still cohesive since other devices exist (Bahaziq, 2016).

All in all, cohesion is crucial in the testing document texts. Cohesion contributes to text readability and comprehensibility (Poudel, 2018; Yule, 2006). The finding of grammatical cohesion devices in this reading text of English Final Examination will improve the quality of the English National Final Examination test text in the term of readability and comprehensibility.

The present study's findings have pedagogical implications for the teacher, teacher educators, language experts, and students in the realm of foreign/second language teaching, particularly and education generally. The pedagogical implication to English teacher and teacher educator, for instance, is to improve and teach students' knowledge and ability of grammatical cohesion devices to equip students with appropriate knowledge regarding grammatical cohesion devices. The improvement of this knowledge and experience will improve students' ability to understand the text because of the cohesiveness. The implication to language experts or scriptwriters may use the variations of grammatical cohesion devices instead of using monotonous kinds of sub-types devices. Then for the students, since the knowledge about cohesiveness is essential to understand the text, they need to be given the material related to cohesion and coherence of the text. They will be exposed to text cohesiveness from an early young age. It is very useful in the mastery of their language, especially in reading and writing skills.

Similarly, students who are taught grammatical cohesive devices significantly enhance their reading comprehension skills. In contrast, the students who had not been taught showed a lack of reading comprehension skills (Bechoua, 2012). She also emphasized that the teacher who designed grammatical cohesion devices in the courses explicitly proved to improve the students' comprehension of grammar knowledge and the meaning and function. Such ability will improve students' English literacy, especially in reading and writing skills, in the future.

\section{CONCLUSION}

The study has found that the reference becomes the most use grammatical cohesion device component compared with other devices. The conjunction is in the second place, followed by substitution and ellipsis in the last position. In the reference category, the personal reference becomes the most dominant grammatical cohesion device use. In the conjunction devices category, additive conjunction becomes the most dominant and takes frequent conjunction in English Final Examination. Meanwhile, in the substitution category, verbal substitution is the most frequent use in the reading text, and verbal ellipsis is the most dominant in the ellipsis category. The data also assumed that the English National Final 
Examination text is only familiar with some types or kinds of grammatical cohesion devices.

Moreover, there is any limitation use of some various sub-types of grammatical cohesion devices; the chosen devices are monotonous and are repeated multiple times. Sub-types grammatical cohesion devices, especially in adversative conjunction, need to be improved by giving variations kinds of grammatical cohesion devices sub-types specifically in conjunction devices. It will provide the opportunity for students to expose to different variations of grammatical cohesion devices. Hence, the students will be more familiar with various grammatical cohesion devices.

\section{REFERENCES}

Abdurahman, N. H. (2013). Grammatical Cohesion Analysis of Students' Thesis Writing. Jurnal Pendidikan Dan Pembelajaran Khatulistiwa, 2(11), 1-18.

Afrianto, A. (2017). Grammatical Cohesion in Students' Writing: a Case At Universitas Teknokrat Indonesia. LEKSEMA: Jurnal Bahasa Dan Sastra, 2(2), 97. https://doi.org/10.22515/ljbs.v2i2.899

Almutairi, N. D. (2017). Discourse Analysis of Cohesive Devices in Saudi Student's Writing. World Journal of Educational Research, 4(4), 516. https://doi.org/10.22158/wjer.v4n4p516

Ardanellia, A. S., \& Pasaribu, T. A. (2019). The Use of Conjunctions in High School Students' Descriptive Paragraphs. Elite, 6(2), 173-185.

Badan Standar Nasional Pendidikan. (2017). Kisi-kisi USBN dan UN Tahun Pelajaran 2017/2018. https://bsnp-indonesia.org/2017/08/kisi-kisi-usbn-danun-tahun-pelajaran-20172018/

Bahaziq, A. (2016). Cohesive Devices in Written Discourse: A Discourse Analysis of a Student's Essay Writing. English Language Teaching, 9(7), 112. https://doi.org/10.5539/elt.v9n7p112

Bechoua, S. (2012). Teaching grammatical cohesive devices to enhance reading comprehension the case of the first year students university of Larbi Ben M'hidi, Oum el Bouaghi [Constantine University]. http://193.194.84.142/theses/anglais/BEC1332.pdf

Ekawati, Y. N., Jamaludin, S., \& Liswildayanti, N. (2011). Analisis Kohesi Dalam Teks Bacaan (Reading Text) Pada " Ujian Nasional Tahun Pelajaran 2009 / 2010 Bahasa Inggris ” Untuk Sekolah Menengah Atas ( SMA ) Research Institution and Community Service of Universitas Pancasakti Tegal.

Faizah, Sutopo, D., \& Faridi, A. (2020). The Use of Cohesive Devices in English Education Journal Articles Written by Graduate Students of Universitas Negeri Semarang. 10(2), 208-213.

Halliday, M.A.K., \& Hasan, R. (1976). Cohesion in English. Longman. https://doi.org/https://doi.org/10.4324/9781315836010

Laeli, M. (2015). an Analysis of Lexical and Grammatical Cohesion on Advertisements of the Jakarta Post Newspaper English Letters Departement Adab and Humanities Faculty State Islamic University Syarif Hidayatullah.

Luke, A., \& Dooley, K. (2011). Critical literacy and second language learning. In Handbook of Research in Second Language Teaching and Learning (Vol. 2). https://doi.org/10.4324/9780203836507.ch51 
McDonough, J. (2002). Issues in Applied Linguistics. M. McCarthy. ELT Journal, 56(1), 96-99. https://doi.org/10.1093/elt/56.1.96

Nasser, A. N. A. (2017). A study of errors in the use of grammatical cohesive devices in argumentative texts written by Yemeni EFL learners. International Journal of Appl Ied Research, 3(10), 172-176.

Nugraheni, R. (2015). Cohesive Devices in Learners' Writing. Language and Language Teaching Journal, 18(01), 51-62. https://doi.org/10.24071/1lt.2015.180106

Oshima, Alice \& Hogue, A. (2006). Writing Academic English. Addison Wesley Publishing Company.

Pasaribu, T. A. (2017). Male and Female Students' Use of Textual Discourse Markers in Writing Academic Essays. Journal of Language and Literature, 17(1), 74-81. https://doi.org/10.24071/joll.2017.170108

Poudel, A. P. (2018). Academic Writing : Coherence and Cohesion in Paragraph Academic writing : Coherence and Cohesion in Paragraph. January, 0-10.

Trisnaningrum, Y., Alek, A., \& Hidayat, D. N. (2019). Discourse Analysis of Grammatical Cohesion Devices in College Students' Academic Writing Essay. IJEE (Indonesian Journal of English Education), 6(1), 79-90. https://doi.org/10.15408/ijee.v6i1.12502

UNESCO. (2012). Opportunities Lost: The Impact Of Grade Repetition And Early School Leaving.

Yule, G. (2006). The Study of Language (3rd ed.). Cambridge University Press. https://escholarship.org/uc/item/3j30945f

* Surat dari PUSPENDIK nomor 6293/H4.2/KP/2018 tanggal 5 Juni 2018 perihal Undangan Penulisan Soal Online SIAP 


\section{APPENDICES \\ The Copysheet of English National Final Examination}

1.

2.

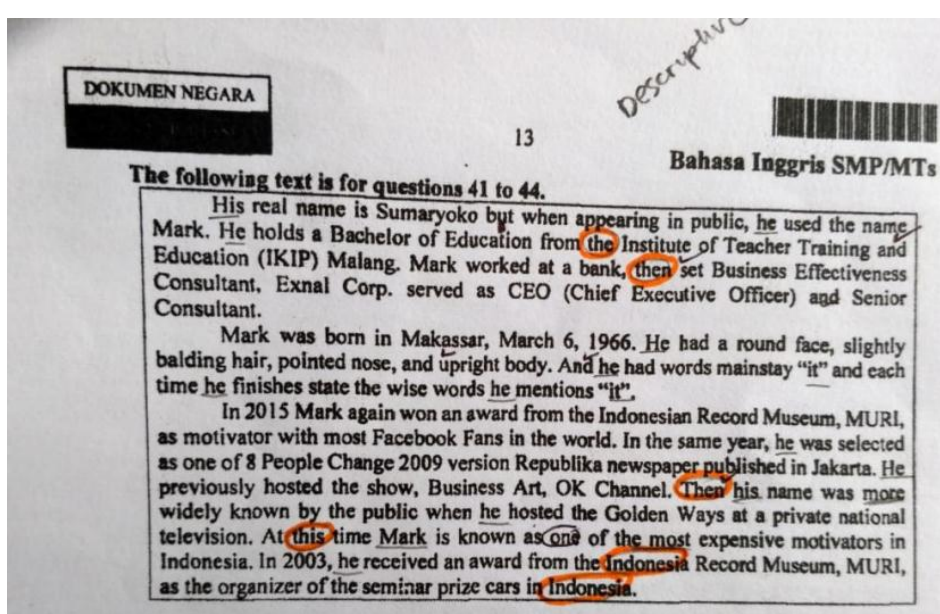

41. The purpose of the text is ....
A. to announce that Mark won many awards.
B. to entertain the readers with the Mark's talent.
C. to inspire the readers with Mark's achievemen.
D. to tell how Mark becomes a popular motivator.

To reach the waterfall location, we should go on foot, after having a three-hour trip on a motorcycle from Bandarlampung, the capital city of Lampung. When we arrived there) I was amazed by the beautiful scenery of the waterfall. The water was so clean and fresh at that time and 1 coula not bear to jump into it immediately. It was quite windy there andall l could see only green, green, and green. Hearing the sound guite windy there andall could see only green, green, and green. He

of falling water while swimming made me feel peaceful and relaxed.
Finally, the day was getting dark and it was time for us to gotomelt was such an unforgettable experience for me that I really enjoyed.

45. The sound of falling water made the writer ...

A. want to swim.

B. contemplate.

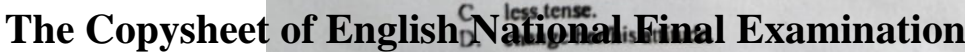

3.

46. The water in Lembah Pelangi waterfall is clean and fresh. It's probably due to its location is ....

A. in the green area

Bahasa Inggris SMP/MTs

Read the text and answer/the following questions 33 to 36 .

A mother duck and her little ducklings were on their way to a (ako one day.

The ducklings were very happy following their mother an quack-quacking along the way. All of a sudden the mother duck saw a fox at a distance She was frightened and shouted, "Children, hurry to the lake. There s a fox!"

The ducklings hurried towards the lake. The mother duck wondered what to do. She began to walk back and forth dragging one wing on the ground. When the fox saw her, he became happy. He said to himself, "It seems that she's hurt and can't fly! I can easily catch and eat her!" Then he ran towards her.

The mother duck ran, leading the fox away from the lake. The fox followed er. Tow he wouldn't be able to harm her ducklings. The mother duck looked her. Sher wack relieved So she stopped and took a deep breath. The fox thought she was tired ante he came cio she anded in the middle of the lake and her ducklings swam to her.

The for stared in disbelief at the mother duck and her ducklings. He reach them because they were in the middle of the lake. In this way she fooled her enemy thinking she was hurt. When the enemy followed her this gave her children time to escape.

33. What does the text tell us about?

A. A tricky fox in finding his prey.

$R_{p}=118$

B. A smart duckling in running away from a fox.

C. A good effort of the ducklings in searching food.

D. A clever way of mother duck protecting her little ducklings.

34. What is the main idea of the third paragraph?

A. Mother duck tricked the fox to save her ducklings.

B. The fox was finally succeeded to get the ducklings.

C. Mother duck ran away from the fox and left the lake.

D. The fox was successful to take the mother duck away.

35. What 'would happen to mother duck if she didn't pretend to be hurt? She would ...

A. be caught by the fox

C. run away soon

C. run away

36. From the texi we learn that we have to be ..

A. smart to save ourselves from the enemy
B. caln to make the enemy run away
C. smart to make the enemy happy

C. calm to save the time

(ब). 
Table of Spesification:

\begin{tabular}{|l|l|l|l|l|l|l|l|l|l|l|l|}
\hline $\begin{array}{l}\text { Text/ } \\
\text { page }\end{array}$ & \multicolumn{3}{|c|}{ References } & \multicolumn{3}{c|}{ Substitution } & \multicolumn{3}{c|}{ Cllipsis } & \multicolumn{3}{c|}{ Conjunction } \\
\hline $\mathbf{1 / 1 1}$ & Personal & Demonstrative & Comparative & Nominal & Verbal & Causal & Nominal & Verbal & Causal & Additive & Adversative \\
\hline $\mathbf{2 / 1 3}$ & & & & & & & & & & & \\
\hline $\mathbf{3 / 1 4}$ & & & & & & & & & & & \\
\hline $\mathbf{4}$ & & & & & & & & & & & \\
\hline
\end{tabular}

Note:

1. Column text: Fill with the text and and the page number of the text

2. Column References, Substitution, Ellipsis, and Conjunctions fills with the number of cohesion devices that exist in the text 